\title{
Analisa Pengukuran Kinerja Perusahaan PT. BCV dengan Menggunakan Konsep Balanced Scorecard
}

\author{
Pratiwi Hendro Wahyudiono ${ }^{1 *}$, Nanang Alamsyah ${ }^{1}$, dan Ansyar Bora ${ }^{1}$ \\ ${ }^{1}$ Program Studi Teknik Industri, Sekolah Tinggi Teknik Ibnu Sina Batam, Indonesia.
}

Article History
Received:
03.02 .2019
Revised:
23.04 .2019
Accepted:
28.05.2019
*Corresponding Author:
Pratiwi Syair
Email:
tiwisyair@gmail.com

Abstrak: Dalam rangka mencapai peningkatan pemasaran dan pendapatan di PT BCV, perusahaan harus melakukan perbaikan dengan melakukan pengukuran kinerja. Model CIPP digunakan untuk menyelesaikan studi ini dengan studi Input dalam bentuk pernyataan perusahaan, strategi perusahaan dan target dan realisasi masing-masing KPI. Penentuan KPI penulis menggunakan metode wawancara kepada setiap kepala bidang dan manager bertugas menentukan KPI yang akan dilakukan pembobotan dengan menggunakan konsep pendukung keputusan yaitu AHP. Perhitungan kinerja KPI dilakukan dengan membandingkan target dan realisasi. Dari 32 strategi yang berikan setiap kepala bidang, hanya 15 yang dipilih oleh manager sebagai KPI. Hasil pembobotan setiap perspektif yaitu pada perspektif pelanggan sebesar 0,5476, perspektif Pembelajaran \& Pertumbuhan sebesar 0,2559, perspektif Proses Bisnis Internal sebesar 0,1448 dan perspektif keuangan sebesar 0,0517. Hasil perhitungan skor KPI secara keseluruhan sebesar 0,0517 dan dalam lalu lintas masuk ke dalam katagori warna merah yang berarti kinerja perusahaan TV kabel berada diposisi yang sangat rendah. Saran yang diberikan untuk dilakukan evaluasi yaitu Perspektif Pelanggan dan Perspektif Proses Bisnis Internal.

Kata Kunci: Balanced Scorecard, Key Performance Indicator, Analitycal Hierarchy Process.

Analysis of Company Performance Measurement PT. BCV by Using the Balanced Scorecard Concept

Abstract: In order to achieve increased marketing and revenue in PT BCV, the company must make improvements by measuring the performance. The CIPP model is used to complete this study with Input study in the form of company statement, corporate strategy and target and realization of each KPI. Determination of KPI authors use the interview method to each head of the field and manager in charge of determining the KPI which will be weighted by using the decision support concept that is Analitycal Hierarchy Process (AHP). KPI performance calculation is done by comparing the targets and realization. Of the 32 strategies that give each head of the field, only 15 are selected by the manager as KPI. The weighting result of each perspective is on the customer perspective of 0.5476 , Learning \& Growth of 0.2559 , Internal Business Process of 0.1448 and financial of 0.0517 . The calculation results of overall KPI score of 0.5017 in the traffic light into the category of red color which means the performance of cable TV companies are positioned very low. Suggestions given for evaluation are Customer Perspective and Internal Business Process Perspective.

Keywords: Balanced Scorecard, Key Performance Indicator, Analitycal Hierarchy Process. 


\section{Pendahuluan}

PT BCV didirikan di Batam pada tahun 2006, yang berlokasi di Komplek Bumi Indah Blok III No. 17. Perusahaan ini bergerak dibidang pendistribusian siaran televisi nasional maupun internasional. Sistem pendistribusian menggunakan jaringan kabel yang digelar di sekitaran lokasi head end PT $\mathrm{BCV}$, karena menggunakan jaringan kabel sehingga masyarakat lebih mengenal dengan nama TV Kabel [1].

Berlokasi di salah satu pusat bisnis di Kota Batam, pendirian perusahaan TV kabel ini dimaksudkan untuk memenuhi keinginan masyarakat yang ingin mendapatkan informasi yang cepat dan bermanfaat dengan harga terjangkau. Selain itu dengan adanya TV kabel ini dimaksudkan untuk menambah semarak bisnis hiburan melalui media kaca, karena selama ini masyarakat hanya mengenal siaran free to air yang dapat dinikmati secara gratis tetapi channel-channel free to air (FTA) tersebut hanya menayangkan siaran-siaran lokal dan siaran luar yang tidak begitu menarik sedangkan jika memasang TV kabel masyarakat dapat menikmati siaran-siaran dengan kualitas gambar setara dengan kualitas Digital Versatile Disc (DVD) [2].

Pada saat ini layanan penyiaran dalam bentuk televisi berlangganan semakin populer dan diminati oleh sebagian masyarakat di Indonesia. Ini terbukti dengan tingkat pertumbuhan pelanggan televisi berlangganan di Indonesia yang cukup tinggi dibandingkan pertumbuhan pelanggan televisi berlangganan di tingkat Asia Tenggara. Data menunjukkan, bahwa jumlah pelanggan di televisi berlangganan di Indonesia adalah sekitar 900 ribu dan angka ini baru sekitar $9 \%$ dari total potensi market televisi berlangganan di Indonesia [3]. Namun, di tahun 2016, layanan TV kabel mengalami penurunan yang disebabkan oleh terus berkembangnya teknologi dan jaringan, hal tersebut dibuktikan dari semakin meninggkatnya pengguna gawai atau telepon pintar yang lebih memilih menonton film yang disukai melalui media streaming YouTube menggunakan Wireless Fidelity (WIFI) dibandingkan menonton televisi dan dengan semakin berkembangnya teknologi banyak perusahaan besar yang menawarkan jaringan TV kabel beserta internet, seperti dilansir oleh Fajrina, Hani Nur [4] setelah mempercepat penyelenggaraan 4G LTE memanfaatkan spectrum $900 \mathrm{MHz}$ dan $1.800 \mathrm{MHz}$, Menteri Komunikasi dan Informatika mengatakan akan fokus mengembangkan jaringan pita-lebar tetap (fixed broadband) di 2016 dan tahun depan fokusnya fixed broadband yang bisa dibawa kerumah untuk telepon, data, internet dan TV kabel.

Kinerja adalah hasil yang diperoleh oleh suatu organisasi baik organisasi yang bersifat profit oriented ataupun non-profit oriented yang dihasilkan selama satu periode [5]. Dalam rangka mencapai peningkatan pemasaran, perusahaan harus melakukan perbaikan dengan melakukan pengukuran kinerja karena selama ini proses pengukuran kinerja PT BCV belum menyeluruh karena masih bersifat konvensional yaitu hanya melihat pada aspek keuangan dan sementara aspek lain seperti aspek pelanggan, aspek pertumbuhan, aspek bisnis internal tidak pernah diukur dalam kurun waktu yang sangat lama sementara ketiga hal tersebut sangat penting dalam pengukuran kinerja. Menurut Pandu Febriarso [6], pengukuran kinerja dapat diartikan sebagai penentuan secara periodik efektifitas operasional bagian organisasi dan personilnya berdasarkan standar dan kriteria yang telah ditentukan sebelumnya. Hingga saat ini metode yang tepat untuk mengukur kinerja perusahaan dengan menggunakan empat perspektif yaitu dengan Balanced scorecard.

\section{Balanced Scorecard}

Balanced scorecard (BSC) adalah pendekatan terhadap strategi manajemen yang dikembangkan oleh

R. S. Kaplan and D. P. Norton [7]. Kelebihan Balanced scorecard yang pertama ialah berfungsi sebagai alat mengkomunikasikan strategi diantara para stakeholders' dari sebuah organisasi. Kedua, BSC memungkinkan organisasi untuk memetakan semua faktor utama yang ada dalam organisasi baik bentuk fisik maupun non-fisik, ketiga BSC dapat mengaitkan strategi dengan kinerja organisasi. Keempat, BSC memiliki konsep sebab akibat dan yang kelima BSC dapat membantu proses penyusunan anggaran. Dengan adanya BSC maka pihak manajemen dapat berfokus pada ukuran kinerja sambil menyeimbangkan sasaran finansial dengan perspektif keuangan, pelanggan, proses bisnis internal serta pembelajaran dan pertumbuhan. Pendekatan Balance Scorecard ini telah banyak dipergunakan dalam berbagai penelitian untuk menentukan KPI dan Bobot Kinerja suatu perusahaan diantaranya adalah M. Hermansyah [8], Nanang Alamsyah [9], dan Hendri Syafriono [10]. Konsep Balanced scorecard ini pada dasarnya merupakan penerjemahan strategi dan tujuan yang ingin dicapai oleh suatu institusi dalam jangka panjang.

Pada umumnya, tahapan pengukuran kinerja dibagi menjadi lima tahapan, yaitu mendesain, mengevaluasi hasil pengukuran, merencanakan, dan mengevaluasi kembali sistem pengukuran kinerja 
[11]. Tahapan tersebut merupakan siklus berkelanjutan. Proses mendesain berawal dari menentukan model apa yang dipilih, termasuk kerangka kerjanya, sampai penentuan Key Perfomance Indicator (KPI).

\section{Penentuan KPI}

Penentuan KPI didasarkan pada wawancara yang dilakukan kepada manager operasional dan kepala bidang. Penentuan ini perlu dilakukan untuk mengetahui kondisi kinerja perusahaan. Gambar 1 menggambarkan KPI yang telah dirumuskan dalam penelitian ini.

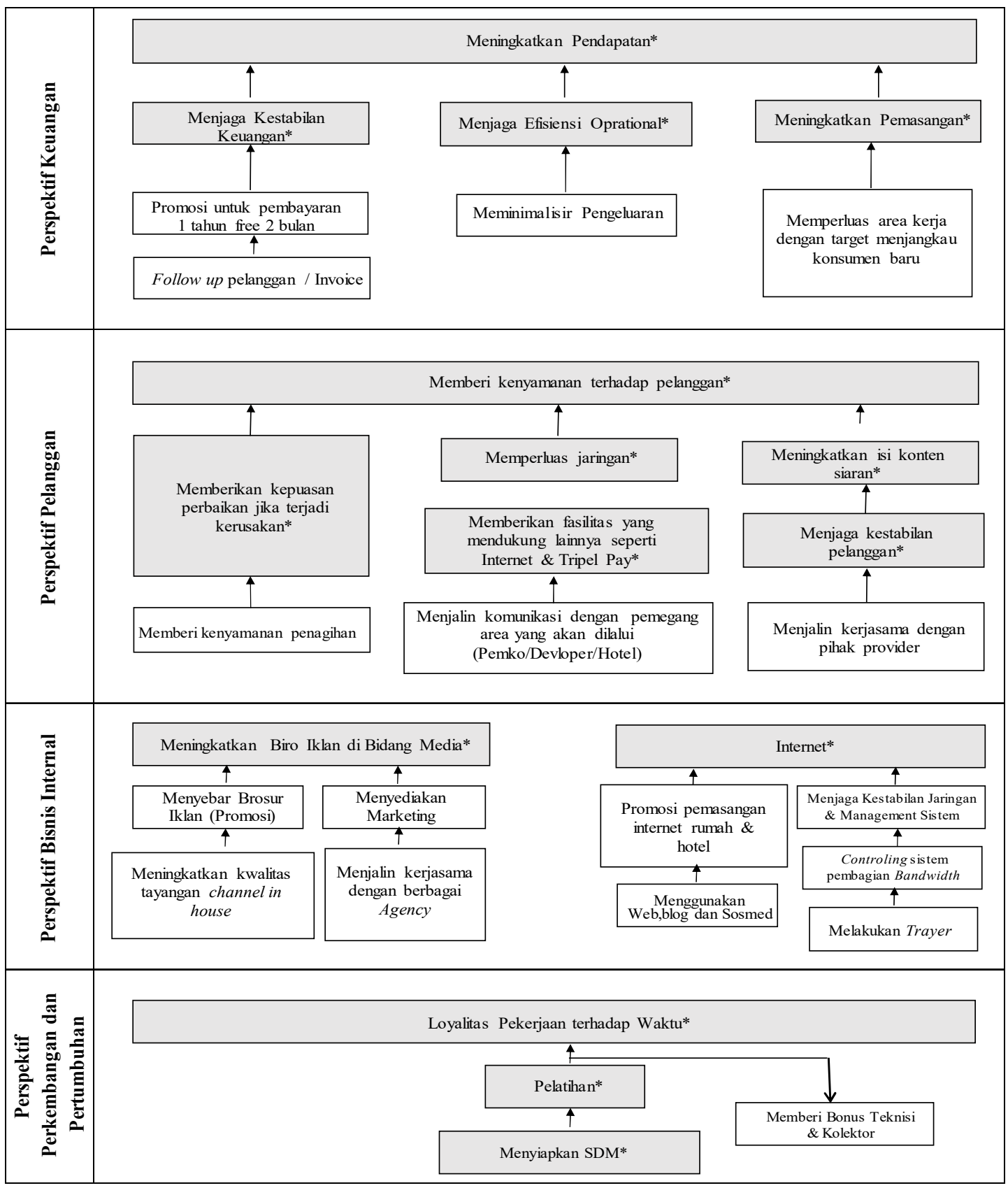

Gambar 1. Inisiatif Strategi PT. BCV (Kotak Warna Abu-Abu)

Penentuan inisiatif strategi PT BCV menghasilkan program pengerak pada masing-masing sasaran strategi dalam perspektif BSC. Penentuan prioritas utama inisiatif strategi menggunakan metode Analytical Hierarchy Process (AHP). Ketika mengaplikasikan AHP, ada tiga prinsip pokok yang 
harus diperhatikan yaitu prinsip penyusunan hierarki, prinsip menentukan prioritas, dan prinsip konsistensi logis [12] [13]. Salah satu cara pengembangan hierarki adalah dengan penentuan prioritas inisiatif strategi berdasarkan pada rancangan BSC. Susunan tingkatan hierarki penentuan inisiatif strategi BSC dapat dilihat pada Gambar 1.

Susunan hierarki pada level pertama menjelaskan tujuan utama yang akan dicapai perusahaan melalui proses hierarki. Tujuan utama dari struktur hierarki adalah penentuan prioritas inisiatif strategi. Berdasarkan hasil pengolahan terhadap level pertama diperoleh bobot dan prioritas kriteriakriteria yang berpengaruh terhadap pengambilan keputusan inisiatif strategi [14] [15].

Level kedua dari struktur hierarki adalah kriteria. Kriteria merupakan elemen yang terkait dengan tujuan hierarki. Elemen dari kriteria terdiri dari empat perspektif BSC, yaitu finansial, pelanggan, proses bisnis internal, serta pembelajaran dan pertumbuhan. Tujuan menghitung besarnya bobot keempat perspektif BSC adalah untuk mengetahui seberapa besar posisi dan peranan perspektif tersebut terhadap pencapaian tujuan yang diinginkan.

Tabel 1. Bobot dan Prioritas Elemen Kriteria

\begin{tabular}{|l|c|c|}
\hline \multicolumn{1}{|c|}{ Elemen Kriteria } & Bobot & Prioritas \\
\hline \hline Perspektif Pelanggan ( C ) & 0,5476 & 1 \\
\hline Perspektif Pembelajaran dan Pertumbuhan (G) & 0,2559 & 2 \\
\hline Perspektif Proses Bisnis Internal ( I ) & 0,1448 & 3 \\
\hline Perspektif Finansial ( F ) & 0,0517 & 4 \\
\hline
\end{tabular}

\subsection{Perspektif Finansial}

Inisiatif strategi dalam perspektif finansial terdiri dari meningkatkan pendapatan (F1), menjaga kestabilan keuangan (F2), meningkatkan pemasangan (F3), dan menjaga efisiensi operasional (F4). Hasil kuesioner pembobotan yang telah direvisi dapat dilihat pada Tabel 2.

Tabel 2. Bobot dan Prioritas Inisiatif Strategi Perspektif Finansial

\begin{tabular}{|l|c|c|}
\hline \multicolumn{1}{|c|}{ Alte rnatif Inisiatif Strategi } & Bobot & Prioritas \\
\hline \hline Meningkatkan Pemasangan (F3) & 0.0322 & 1 \\
\hline Menjaga Kestabilan Keuangan (F2) & 0.0112 & 2 \\
\hline Menjaga Efisiensi Operasional (F4) & 0.0055 & 3 \\
\hline Meningkatkan Pendapatan (F1) & 0.0028 & 4 \\
\hline
\end{tabular}

Tabel 2 menunjukkan bahwa inisiatif strategi peningkatan pemasangan (F3) memiliki bobot tertinggi diantara keempat inisiatif strategi tersebut. Hal ini menyebabkan pemasangan menempati prioritas tertinggi.

Tabel 3. Bobot dan Prioritas Inisiatif Strategi Perspektif Pelanggan

\begin{tabular}{|l|c|c|}
\hline \multicolumn{1}{|c|}{ Alternatif Inisiatif Strategi } & Bobot & Prioritas \\
\hline \hline Memberikan kenyamanan terhadap pelanggan (C1) & 0.2435 & 1 \\
\hline Memberikan kepuasan perbaikan jika terjadi kerusakan (C2) & 0.1715 & 2 \\
\hline Meningkatkan isi konten siaran (C4) & 0.0541 & 3 \\
\hline Menjaga kestabilan pelanggan (C6) & 0.0354 & 4 \\
\hline Memberikan fasilitas yang mendukung lainnya (C5) & 0.0299 & 5 \\
\hline Memperluas jaringan (C3) & 0.0132 & 6 \\
\hline
\end{tabular}




\subsection{Perspektif Pelanggan}

Inisiatif strategi pelanggan terdiri dari memberikan kenyamanan terhadap pelanggan (C1), memberikan kepuasan perbaikan jika terjadi kerusakan (C2), memperluas jaringan (C3), meningkatkan isi konten siaran (C4), memberikan fasilitas yang mendukung lainnya (C5), dan menjaga kestabilan pelanggan (C6). Hasil kuesioner pembobotan yang telah direvisi dapat dilihat pada Tabel 3.

Tabel 3 menunjukkan bahwa inisiatif strategi memberikan kenyamanan terhadap pelanggan memiliki bobot yang lebih besar diantara keenam perspektif yang ada. Hal ini menyebabkan inisiatif strategi memberikan kenyamanan terhadap pelanggan memiliki prioritas lebih tinggi dibandingkan keenam inisiatif strategi lainnya.

\subsection{Perspektif Proses Bisnis Internal}

Inisiatif strategi dalam perspektif proses bisnis internal terdiri dari meningkatkan biro iklan dibidang media (I1) dan internet (I2). Hasil kuesioner pembobotan yang telah direvisi dapat dilihat pada Tabel 4.

Tabel 4. Bobot dan Prioritas Inisiatif Strategi Perspektif Proses Bisnis Internal

\begin{tabular}{|l|c|c|}
\hline \multicolumn{1}{|c|}{ Alternatif Inis iatif Strategi } & Bobot & Prioritas \\
\hline \hline Meningkatkan Biro Iklan di bidang Media (I1) & 0.1086 & 1 \\
\hline Internet (I2) & 0.0362 & 2 \\
\hline
\end{tabular}

Tabel 4 menunjukkan bahwa inisiatif strategi meningkatkan biro iklan di bidang media memiliki nilai bobot paling tinggi dibandingkan dengan internet. Hal ini menyebabkan inisiatif meningkatkan biro iklan di bidang media memiliki prioritas lebih tinggi dibandingkan dengan internet.

\subsection{Perspektif Pembelajaran dan Pertumbuhan}

Inisiatif strategi dalam perspektif pertumbuhan dan pembelajaran terdiri dari loyalitas pekerjaan terhadap waktu (G1), pelatihan (G2), dan menyiapkan SDM (G3). Hasil kuesioner pembobotan yang telah direvisi dapat dilihat pada Tabel 5 .

Tabel 5. Bobot dan Prioritas Inisiatif Strategi Perspektif Pembelajaran dan Pertumbuhan

\begin{tabular}{|l|c|c|}
\hline \multicolumn{1}{|c|}{ Alternatif Inisiatif Strategi } & Bobot & Prioritas \\
\hline \hline Loyalitas pekerja terhadap waktu (G1) & 0.1677 & 1 \\
\hline Menyediakan SDM (G3) & 0.0478 & 2 \\
\hline Pelatihan (G2) & 0.0404 & 3 \\
\hline
\end{tabular}

Table 5 menunjukkan bahwa inisiatif strategi loyalitas terhadap waktu memiliki nilai bobot tertinggi dibandingkan dengan inisiatif strategi yang lain. Hal ini menyebabkan inisiatif strategi loyalitas terhadap waktu memiliki prioritas lebih tinggi dibandingkan dengan inisiatif strategi lainnya.

Inisiatif strategi Balanced Scorecard pada PT BCV menerangkan bahwa memberikan kenyamanan terhadap pelanggan memiliki pengaruh yang paling besar terhadap keberhasilan kinerja perusahaan karena memiliki bobot terbesar diantara inisiatif strategi lainnya.

Hasil pembobotan dan paparan terhadap inisiatif strategi Balanced Scorecard pada PT BCV dapat dilihat pada Gambar 2. 


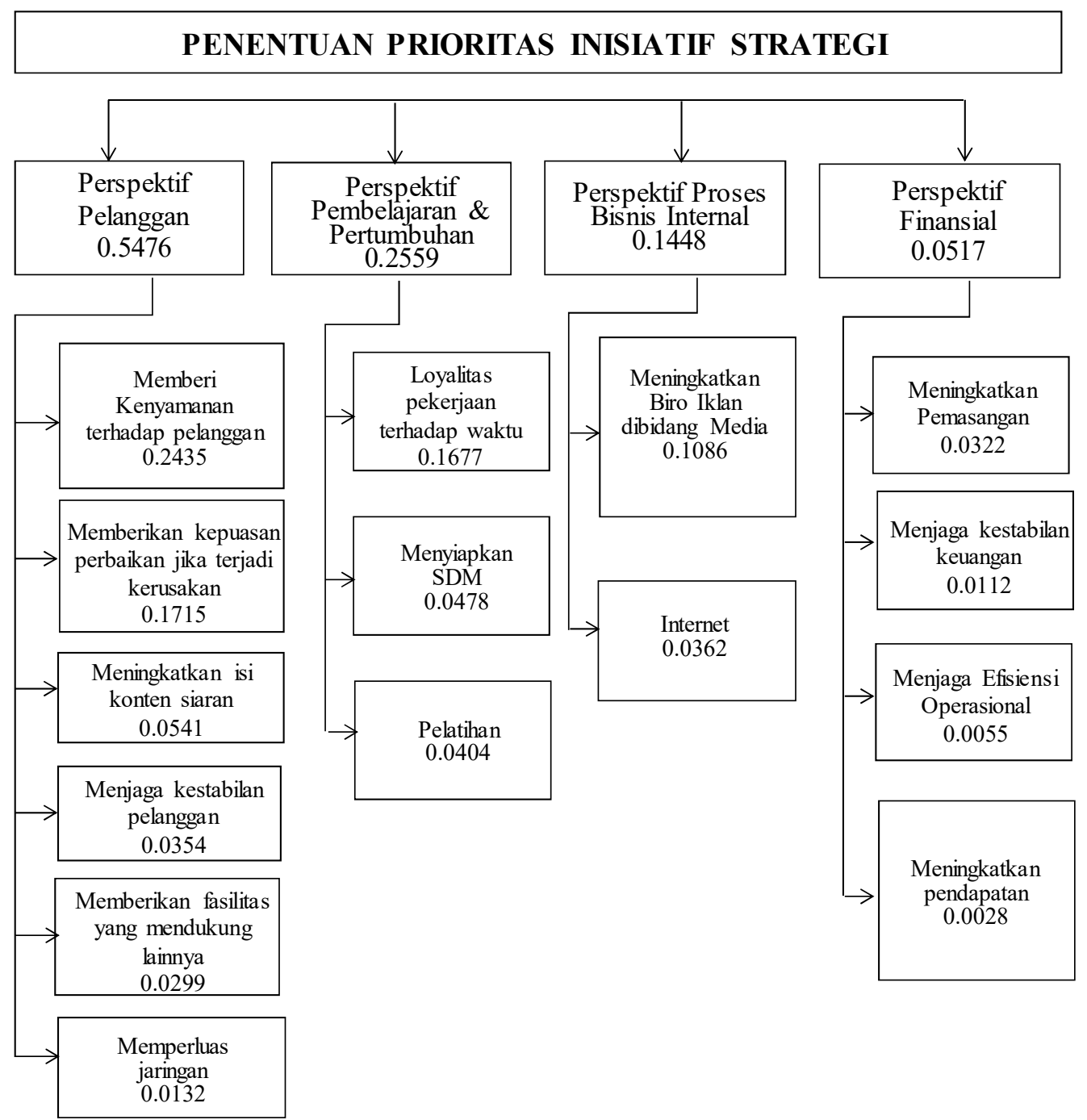

Gambar 2. Penentuan Inisiatif Strategi Balanced Scorecard

\section{Penentuan Target dan Pengukuran Kinerja}

Langkah terakhir yang selanjutnya dilakukan adalah penentuan target dan pengukuran kinerja dari masing-masing inisiatif strategi. Target dari tiap inisiatif strategi telah ditentukan di awal tahun 2016, sedangkan target di tahun 2013-2015 belum ditentukan. Sehingga tidak mungkin dilakukan pengukuran kinerja di tahun 2013-2015.

\subsection{Perspektif Finansial}

Berikut adalah target yang telah ditentukan oleh PT BCV di tiap inisiatif strategi perspektif finansial:

1. Peningkatkan pendapatan di tahun 2016 sebesar $50 \%$

2. Menjaga kestabilan keuangan di tahun 2016 sebesar $70 \%$

3. Meningkatkan Pemasangan di tahun 2016 sebesar $40 \%$

4. Menjaga efisiensi operasional di tahun 2016 sebesar $70 \%$. 
Tabel 6. Pendapatan dan Pengeluaran PT. BCV

\begin{tabular}{|l|lr|lr|}
\hline \multicolumn{1}{|c|}{ Deskripsi } & \multicolumn{2}{c|}{$\mathbf{2 0 1 5}$} & \multicolumn{2}{c|}{$\mathbf{2 0 1 6}$} \\
\hline \hline Pendapatan & $\mathrm{Rp}$ & $4,794,557,298$ & $\mathrm{Rp}$ & $6,255,546,159$ \\
\hline Pengeluaran & $\mathrm{Rp}$ & $4,538,821,853$ & $\mathrm{Rp}$ & $5,994,143,950$ \\
\hline Laba/Rugi Kotor & $\mathrm{Rp}$ & $255,735,445$ & $\mathrm{Rp}$ & $261,402,209$ \\
\hline
\end{tabular}

Realisasi dari tabel di atas, dapat kita peroleh perhitungan:

1. Realisasi peningkatan pendapatan PT BCV di tahun 2016 adalah

$$
\frac{\mathrm{Rp} \quad 6,255,546,159-\mathrm{Rp} 4,794,557,298}{\operatorname{Rp} 4,794,557,298}=30,47 \%
$$

2. Realisasi menjaga kestabilan keuangan di tahun 2016 adalah

$$
\frac{\mathrm{Rp} \quad 261,402,209-\mathrm{Rp} 255,735,445}{\mathrm{Rp} 255,735,445}=2,22 \%
$$

3. Realisasi meningkatkan pemasangan di tahun 2016 adalah

$$
\frac{\operatorname{Rp}}{\operatorname{Rp}} \frac{111,346,000}{173,673,425}=64,11 \%
$$

4. Realisasi menjaga efiesiensi operasional di tahun 2016 adalah

$$
\begin{array}{ll}
\operatorname{Rp} & 5,994,143,950 \\
\operatorname{Rp} & 6,255,546,159
\end{array}=95.82 \%
$$

Dari perhitungan tersebut, dapat kita hitung kinerja tiap inisiatif strategi dengan cara

\begin{tabular}{|c|c|c|c|c|c|c|c|c|}
\hline \multirow{2}{*}{ Perspektif } & \multirow{2}{*}{ Deskripsi } & \multirow{2}{*}{\multicolumn{2}{|c|}{ Bobot }} & \multicolumn{5}{|c|}{ Tahun 2016} \\
\hline & & & & Target & Realisasi & Kineria & KPI $S c$ & \\
\hline \multirow{4}{*}{ Keuangan } & Meningkatkan pendapatan & 0.0028 & \multirow{4}{*}{$\stackrel{n}{n}$} & $50.00 \%$ & $30.47 \%$ & 0.6094 & 0.0017 & \multirow{4}{*}{ : } \\
\hline & Menjaga kestabilan keuangan & 0.0112 & & $70.00 \%$ & $2.22 \%$ & 0.0317 & 0.0004 & \\
\hline & Meningkatkan pemasangan & 0.0322 & & $40.00 \%$ & $64.11 \%$ & 1.6028 & 0.0516 & \\
\hline & Menjaga efisiensi operasional & 0.0055 & & $70.00 \%$ & $95.82 \%$ & 1.3689 & 0.0075 & \\
\hline
\end{tabular}
membandingkan realisasi dengan terget yang telah dibuat. KPI Score kita dapatkan dengan cara mengalikan kinerja dan bobot.

Tabel 7. Target dan Kinerja Perspektif Finansial

\subsection{Perspektif Pelanggan}

Berikut adalah target yang telah ditentukan oleh PT BCV di tiap inisiatif strategi perspektif pelanggan:

1 Memberikan kenyamanan terhadap pelanggan: sebesar $80 \%$ untuk ukuran puas dan sangat puas.

2 Memberikan kepuasan perbaikan jika terjadi kerusakan: sebesar $80 \%$ untuk ukuran puas dan sangat puas.

3 Memperluas jaringan: sebesar 90\%

4 Meningkatkan isi konten siaran: sebesar $100 \%$

5 Memberi fasilitas yang mendukung lainnya (internet): sebesar $70 \%$

6 Menjaga kestabilan pelanggan: sebesar 70\%

Berikut adalah data-data yang berhasil peneliti kumpulkan sebagai bahan perhitungan realisasi inisiatif strategi perspektif pelanggan:

1. Dalam pengambilan nilai kepuasan pelanggan peneliti melakukan penyebaran kuesioner ke 96 pelanggan TV kabel.

Tabel 8 adalah tabulasi hasil kuesioner yang diperoleh. 
Tabel 8. Data Kuesioner Pelanggan PT. BCV

\begin{tabular}{|c|l|c|c|c|c|c|}
\hline \multirow{2}{*}{ No. } & \multirow{2}{*}{ Pertanyaan } & \multicolumn{5}{c|}{ Tingkat Kepuasan } \\
\cline { 3 - 7 } & & $\mathbf{1}$ & $\mathbf{2}$ & $\mathbf{3}$ & $\mathbf{4}$ & $\mathbf{5}$ \\
\hline \hline 1 & Kualitas tayangan TV kabel & 4 & 11 & 35 & 35 & 11 \\
\hline 2 & Sistem Pelayanan perbaikan TV kabel & 1 & 12 & 29 & 35 & 19 \\
\hline 3 & Sistem penagihan TV kabel & 0 & 1 & 29 & 37 & 29 \\
\hline
\end{tabular}

Tabel 8 merupakan pengukuran kepuasan pelayanan produk, untuk pengukuran kepuasan pelayanan PT BCV belum pernah melakukan evaluasi kepuasan pelanggan terhadap pelayanan tv kabel sehingga pengukuran kepuasan pelayanan tv kabel tidak ada.

Berdasarkan data-data pada Tabel 8, dapat kita peroleh perhitungan:

1 Tingkat Kenyaman pelanggan PT BCV di tahun 2016 sebesar 57.64\%

2 Tingkat Kepuasan perbaikan PT BCV di tahun 2016 sebesar 56.25\%

2. Dalam memperluas jaringan PT BCV mengalami peningkatan di tahun 2016 yaitu sebesar $\frac{7}{14} \times$ 100. Sehingga dalam realisasinya PT BCV sangat konsisten dalam memperluas jaringan di tahun 2016.

3. Dalam tahapan peningkatan isi konten siaran target yang diinginkan oleh perusahaan yaitu $100 \%$, dalam realisasinya perusahaan telah berkerja sama dengan berbagai pihak penyedia saluran siaran tv kabel atau dapat disebut dengan provider. Di tahun 2016 PT BCV tidak bekerja sama dengan OrangeTV, setelah berakhir kontrak dengan pihak OrangeTV, PT BCV kembali bekerja sama dengan pihak ICTA, Skynindo Analog, dan Indovision. Sehingga dalam realisasi meningkatkan isi konten siaran yaitu sebesar $\frac{2}{3}=67 \%$

4. Tingkatan dalam memberikan fasilitas mendukung lainnya yaitu seperti Internet. PT BCV menargetkan sebesar $70 \%$ perkembangan yang diharapkan. Namun perkembangan internet di tahun 2016 PT BCV hanya melakukan triyer personal saja atau kantor sendiri dan belum siap untuk di jual kepelanggan. Sehingga dalam realisasi internet tidak berjalan dan tingkatan realisasinya yaitu sebesar $0 \%$.

5. Tingkatan menjaga kestabilan pelanggan di tahun 2016 sebesar $\frac{405-244}{(405 x 70 \% 6)}=57 \%$. Dikatakan stabil apabila pemutusan tidak lebih besar dari pada pemasangan.

Tabel 9. Data Pemasangan dan Pemutusan PT. BCV Tahun 2016

\begin{tabular}{|c|c|c|}
\hline No & Pemasangan & Pemutusan \\
\hline \hline 1 & 36 & 36 \\
\hline 2 & 41 & 43 \\
\hline 3 & 28 & 28 \\
\hline 4 & 36 & 1 \\
\hline 5 & 29 & 2 \\
\hline 6 & 34 & 7 \\
\hline 7 & 26 & 24 \\
\hline 8 & 27 & 17 \\
\hline 9 & 39 & 13 \\
\hline 10 & 47 & 13 \\
\hline 11 & 34 & 28 \\
\hline 12 & 28 & 32 \\
\hline TOTAL & $\mathbf{4 0 5}$ & $\mathbf{2 4 4}$ \\
\hline
\end{tabular}


Dari perhitungan yang ditabulasi pada Tabel 9, kinerja tiap inisiatif strategi dihitung dengan cara membandingkan realisasi dengan target yang telah dibuat. KPI Score didapatkan dengan cara mengalikan kinerja dan bobot.

Tabel 10. Target dan Kinerja Perspektif Pelanggan

\begin{tabular}{|c|c|c|c|c|c|c|c|c|}
\hline \multirow{2}{*}{ Perspektif } & \multirow{2}{*}{ Deskripsi } & \multirow{2}{*}{\multicolumn{2}{|c|}{ Bobot }} & \multicolumn{5}{|c|}{ Tahun 2016} \\
\hline & & & & Target & Realisasi & Kinerja & \multicolumn{2}{|c|}{ KPI Scort } \\
\hline \multirow{6}{*}{ Pelanggan } & Memberi kenyamanan terhadap pelanggan & 0.2435 & \multirow{6}{*}{\begin{tabular}{l}
0 \\
\multirow{7}{*}{} \\
$n$ \\
0 \\
0
\end{tabular}} & $80.00 \%$ & $57.64 \%$ & 0.7205 & 0.1754 & \\
\hline & Memberi kepuasan perbaikan jika terjadi kerusakan & 0.1715 & & $80.00 \%$ & $56.25 \%$ & 0.7031 & 0.1206 & \\
\hline & Memperluas jaringan & 0.0132 & & $90.00 \%$ & $100.00 \%$ & 1.1111 & 0.0147 & $n$ \\
\hline & Meningkatkan isi konten siaran & 0.0541 & & $100.00 \%$ & $66.67 \%$ & 0.6667 & 0.0361 & $\stackrel{m}{0}$ \\
\hline & Memberikan fasilitas yang mendukung lainnya & 0.0299 & & $70.00 \%$ & $0.00 \%$ & 0.0000 & 0.0000 & \\
\hline & Menjaga kestabilan pelanggan & 0.0354 & & $70.00 \%$ & $56.79 \%$ & 0.8113 & 0.0287 & \\
\hline
\end{tabular}

\subsection{Perspektif Proses Internal Bisnis}

Berikut adalah terget yang telah ditentukan oleh PT BCV di tiap inisiatif strategi perspektif Proses Bisnis Internal:

1. Meningkatkan Biro iklan dibidang media sebesar $30 \%$

2. Internet sebesar $20 \%$

Dari informasi manager operational PT BCV, realisasi kedua inisiatif strategi tersebut adalah sebagai berikut:

1. Peningkatan Biro iklan di tahun 2016 sebesar

$$
\frac{\mathrm{Rp} \quad 55,330,000-\mathrm{Rp} 118,556,988}{\mathrm{Rp} 118,556,988}=-53 \%
$$

2. Tingkat realisasi pendapatan sebesar $0 \%$, karena belum adanya pendapatan dan pengeluaran.

Dari perhitungan tersebut, dapat kita hitung kinerja tiap inisiatif strategi dengan cara membandingkan realisasi dengan target yang telah dibuat. KPI Score didapatkan dengan cara mengalikan kinerja dan bobot.

Tabel 11. Target dan Kinerja Perspektif Bisnis Internal

\begin{tabular}{|c|c|c|c|c|c|c|c|c|}
\hline \multirow{2}{*}{ Perspektif } & \multirow{2}{*}{ Deskripsi } & \multirow{2}{*}{\multicolumn{2}{|c|}{ Bobot }} & \multicolumn{5}{|c|}{ Tahun 2016} \\
\hline & & & & \multirow{2}{*}{$\begin{array}{l}\text { Target } \\
30.00 \%\end{array}$} & \multirow{2}{*}{\begin{tabular}{|l} 
Realisasi \\
$-53.33 \%$
\end{tabular}} & \multirow{2}{*}{$\begin{array}{l}\text { Kinerja } \\
-1.7777\end{array}$} & \multicolumn{2}{|c|}{ KPI Score } \\
\hline \multirow{2}{*}{ Internal Proses } & Meningkatkan biro iklan dibidang media & 0.1086 & $\stackrel{\infty}{+}$ & & & & -0.1931 & $\bar{n}$ \\
\hline & Internet & 0.0362 & 0 & $20.00 \%$ & $0.00 \%$ & 0.0000 & 0.0000 & i \\
\hline
\end{tabular}

\subsection{Perspektif Pertumbuhan dan Perkembangan}

Berikut adalah target yang telah ditentukan oleh PT BCV di tiap inisiatif strategi perspektif pembelajaran dan pertumbuhan:

1. Loyalitas pekerjaan terhadap waktu sebesar $90 \%$

2. Pelatihan sebesar $80 \%$

3. Menyiapkan SDM $90 \%$

Berikut adalah data-data yang berhasil peneliti kumpulkan sebagai bahan perhitungan realisasi inisiatif strategi perspektif pertumbuhan dan perkembangan:

1. Loyalitas pekerjaan terhadap waktu ditahun 2016 sebesar $100 \%$, diukur dari perbaikan yang dilakukan teknisi diluar jam kerja.

2. Pelatihan di tahun 2016 sebesar 100\%, Karena di tahun 2016 PT BCV pertama kalinya mengadakan pelatihan mengenai Internet.

3. Menyiapkan SDM di tahun 2016 sebesar $\frac{5-7}{5}=40 \%$ 
Dari perhitungan tersebut, dapat kita hitung kinerja tiap inisiatif strategi dengan cara membandingkan realisasi dengan target yang telah dibuat. KPI Score didapatkan dengan cara mengalikan kinerja dan bobot.

Tabel 12. Target dan Kinerja Perspektif Pertumbuhan dan Perkembangan

\begin{tabular}{|c|c|c|c|c|c|c|c|c|}
\hline \multirow{2}{*}{ Perspektif } & \multirow{2}{*}{ Deskripsi } & \multirow{2}{*}{\multicolumn{2}{|c|}{ Bobot }} & \multicolumn{5}{|c|}{ Tahun 2016} \\
\hline & & & & \multirow{2}{*}{$\begin{array}{l}\text { Target } \\
90.00 \% \\
\end{array}$} & \multirow{2}{*}{$\begin{array}{l}\text { Realisasi } \\
100.00 \% \\
\end{array}$} & \multirow{2}{*}{$\begin{array}{r}\text { Kinerja } \\
1.1111 \\
\end{array}$} & \multicolumn{2}{|c|}{ KPI Score } \\
\hline \multirow{3}{*}{$\begin{array}{l}\text { Pertumbuhan \& } \\
\text { Perkembangan }\end{array}$} & Loyalitas pekerjaan terhadap waktu & 0.1677 & $a$ & & & & 0.1863 & 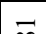 \\
\hline & Pelatihan & 0.0404 & n & $80.00 \%$ & $100.00 \%$ & 1.2500 & 0.0505 & 2 \\
\hline & Menyiapkan SDM & 0.0478 & 0 & $90.00 \%$ & $40.00 \%$ & 0.4444 & 0.0212 & \\
\hline
\end{tabular}

Secara keseluruhan, perhitungan penentuan target dan pengukuran kinerja PT BCV tahun 2016 di keempat perspektif Balanced Scorecard, dapat dilihat pada Tabel 13. Urutan pembobotan tiap perspektif dengan hitungan AHP dari besar ke kecil, sama dengan urutan besarannya KPI Score tiap perspektif dari besar ke kecil.

Tabel 13. Penentuan Target Pengukuran Kinerja

\begin{tabular}{|c|c|c|c|c|c|c|c|c|}
\hline \multirow{2}{*}{ Perspektif } & \multirow{2}{*}{ Deskripsi } & \multirow{2}{*}{\multicolumn{2}{|c|}{ Bobot }} & \multicolumn{5}{|c|}{ Tahun 2016} \\
\hline & & & & \multirow{2}{*}{\begin{tabular}{|c|} 
Target \\
$50.00 \%$ \\
\end{tabular}} & \multirow{2}{*}{\begin{tabular}{|c|} 
Realisasi \\
$30.47 \%$ \\
\end{tabular}} & \multirow{2}{*}{$\begin{array}{r}\text { Kinerja } \\
0.6094\end{array}$} & \multicolumn{2}{|c|}{ KPI Score } \\
\hline \multirow{4}{*}{ Keuangan } & Meningkatkan pendapatan & 0.0028 & \multirow{4}{*}{0.0517} & & & & 0.0017 & \multirow{4}{*}{0.0612} \\
\hline & Menjaga kestabilan keuangan & 0.0112 & & $70.00 \%$ & $2.22 \%$ & 0.0317 & 0.0004 & \\
\hline & Meningkatkan pemasangan & 0.0322 & & $40.00 \%$ & $64.11 \%$ & 1.6028 & 0.0516 & \\
\hline & Menjaga efisiensi operasional & 0.0055 & & $70.00 \%$ & $95.82 \%$ & 1.3689 & 0.0075 & \\
\hline & & & & & & & & \\
\hline \multirow{6}{*}{ Pelanggan } & Memberi kenyamanan terhadap pelanggan & 0.2435 & \multirow{6}{*}{0.5476} & $80.00 \%$ & $57.64 \%$ & 0.7205 & 0.1754 & \multirow{6}{*}{0.3755} \\
\hline & Memberi kepuasan perbaikan jika terjadi kerusakan & 0.1715 & & $80.00 \%$ & $56.25 \%$ & 0.7031 & 0.1206 & \\
\hline & \begin{tabular}{|l|} 
Memperluas jaringan \\
\end{tabular} & 0.0132 & & $90.00 \%$ & $100.00 \%$ & 1.1111 & 0.0147 & \\
\hline & Meningkatkan isi konten siaran & 0.0541 & & $100.00 \%$ & $66.67 \%$ & 0.6667 & 0.0361 & \\
\hline & Memberikan fasilitas yang mendukung lainnya & 0.0299 & & $70.00 \%$ & $0.00 \%$ & 0.0000 & 0.0000 & \\
\hline & Menjaga kestabilan pelanggan & 0.0354 & & $70.00 \%$ & $56.79 \%$ & 0.8113 & 0.0287 & \\
\hline \multirow{2}{*}{ Internal Proses } & Meningkatkan biro iklan dibidang media & 0.1086 & \multirow{2}{*}{0.1448} & $30.00 \%$ & $-53.33 \%$ & -1.7777 & -0.1931 & \multirow{2}{*}{-0.1931} \\
\hline & Internet & 0.0362 & & $20.00 \%$ & $0.00 \%$ & 0.0000 & 0.0000 & \\
\hline \multirow{3}{*}{$\begin{array}{l}\text { Pertumbuhan \& } \\
\text { Perkembangan }\end{array}$} & Loyalitas pekerjaan terhadap waktu & 0.1677 & \multirow{3}{*}{0.2559} & $90.00 \%$ & $100.00 \%$ & 1.1111 & 0.1863 & \multirow{3}{*}{0.2581} \\
\hline & Pelatihan & 0.0404 & & \begin{tabular}{|l|l|}
$80.00 \%$ \\
\end{tabular} & \begin{tabular}{|l|}
$100.00 \%$ \\
\end{tabular} & 1.2500 & 0.0505 & \\
\hline & Menyiapkan SDM & 0.0478 & & $90.00 \%$ & $40.00 \%$ & 0.4444 & 0.0212 & \\
\hline
\end{tabular}

Berdasarkan Tabel 13 diketahui bahwa dari 15 deskripsi KPI setiap perspektif menghasilkan pengukuran kinerja dengan hasil perhitungan keseluruhan yaitu 0.5017 dalam traffic light masuk kedalam katagori warna merah yang berarti kinerja perusahaan TV kabel berada pada posisi yang sangat rendah. Oleh karena itu, dari keempat perspektif yang ada diperusahaan dan harus dilakukan evaluasi yaitu Perspektif Pelanggan dan Perspektif Proses Bisnis Internal, karena KPI Score kedua perspektif tersebut lebih rendah dari bobot yang telah ditetapkan.

\section{Kesimpulan}

Penelitian ini berhasil merancang peta strategi yang didalamnya terdapat Key Performance Indicator (KPI) yang digunakan dalam pengukuran kinerja perusahaan di PT BCV. KPI untuk pengukuran kinerja perusahaan di PT BCV adalah dalam hal perspektif finansial, perspektif pelanggan, perspektif proses bisnis internal, dan perspektif pembelajaran dan pertumbuhan. Berdasarkan perhitungan menggunakan metode AHP, dapat ditarik kesimpulan bahwa kinerja perusahaan secara keseluruhan 
sebesar $50.17 \%$ dan dari pengukuran traffic light kinerja karyawan berada pada posisi warna merah yang berarti kinerja buruk atau rendah.

Saran yang dapat diberikan peneliti yang ditujukan kepada PT BCV adalah pihak manajemen PT BVC perlu segera membuat langkah-langkah strategi baru agar kinerja dan KPI Score perspektif internal bisnis dan perspektif pelanggan segera membaik. Dikhawatirkan jika tidak ada tindakan segera, maka keberlangsungan operasional perusahaan perusahaan akan terganggu karena kunci pendapatan perusahaan di bidang jasa ialah pelanggan, Semakin rendahnya respon pelanggan maka semakin berkurang pendapatan perusahaan. Kemudian, implementasi BSC ini kedepannya bisa diterapkan pada bagian atau tim tertentu di PT BCV untuk mengetahui kinerja dari bagian atau tim tersebut.

\section{Daftar Pustaka}

[1] Anynomous, Laporan Tahunan BCV 2009. Batam: LPB BCV, 2009.

[2] Anynomous, Laporan Tahunan BCV 2010. Batam: LPB BCV, 2010.

[3] S. Gatot, and B. Dewa, B. "Pay TV yang Belum Berizin Yang Perlu Penyelesaian Masalah Keberadaannya Secara Adil Namun Tegas," Dec 2018. [Online]. Available: http://www.sdppi. kominfo.go.id. [Accessed: May 14, 2019].

[4] H. N. Fajrina, "Menkominfo fokus kembangkan Fixed Broadband," CNN Indonesia, Dec 2015. [Online]. Available: http:/www.cnnindonesia.com/teknologi/20151228141230-213-100719/2016-menkominfo-fokus-kembangkan-fixed-broadband/. [Accessed: May 14, 2019].

[5] L. Melati, "Efektivitas Pengukuran Kinerja Badan Kepegawaian Daerah Kota Palopo, 2015. [Online]. Available: http://repository.unhas.ac.id/bitstream/handle/123456789. [Accessed: May 14, 2019].

[6] F. Pandu, Perancangan Sistem Pengukuran Kinerja dengan Metode Perdomance Prims. Surakarta: Universitas Muhammadiyah Surakarta, 2008.

[7] R. S. Kaplan and D. P. Norton, "The Balanced Scorecard: Measures that Drive Performance," Harvard Business Review, vol. 9, no. 4, 1992.

[8] M. Hermansyah, "Perancangan Sistem Manajemen Kinerja dengan Pendekatan Balanced Scorecard di Perguruan Tinggi (Studi Kasus: STT Ibnu Sina Batam)," Unpublished Thesis, STT Ibnu Sina Batam, Batam, Indonesia, 2015.

[9] N. Alamsyah, "Perancangan Sistem Manajemen Kinerja dengan Pendekatan Balanced Scorecard di Perusahaan Startup," Unpublished Thesis, Universitas Mercu Buana, Jakarta, Indonesia, 2015.

[10] H. Syafriono, "Analisa Pengukuran Kinerja Perusahaan Menggunakan Metode Balanced Scorecard pada PT Central Batam Raya," Unpublished Thesis, STT Ibnu Sina Batam, Batam, Indonesia, 2015.

[11] H. Worldailmi, "Perancangan Key Perfomance Indicators (KPI) Sebagai Dasar Alat Pengukuran Kinerja Menggunakan Metode Performance Prims (studi kasus di Taman Pintar Yogyakarta)," Unpublished Thesis, Universitas Sebelas Maret, Surakarta, Indonesia, 2012.

[12] T. L. Saaty, "How to Make a Decision: the Analytical Hierarchy Process," European Journal of Operational Research, vol 48, no. 1, 1990.

[13] A. Sevinç, S. Gür and T. Eren, "Analysis of the Difficulties of SMEs in Industry 4.0 Applications by Analytical Hierarchy Process and Analytical Network Process," processes MDPI, vol. 6, no 26, 2018

[14] K. Seejataa, A. Yodyinga, T. Wongthadama, N. Mahavika, and S. Tantaneeb, "Assessment of flood hazard areas using Analytical Hierarchy Process over the Lower Yom Basin, Sukhothai Province," Procedia Engineering, vol. 212, pp. 340-347, 2018.

[15] R. -S. Wu, L. L. Molina and F. Hussain, "Optimal Sites Identification for Rainwater Harvesting in Northeastern Guatemala by Analytical Hierarchy Process," Water Resources Management, vol. 32, pp. 4139-4153, 2018. 